\title{
Antimüllerian Hormone and Oxidative Stress Biomarkers as Predictors of Successful Pregnancy in Polycystic Ovary Syndrome, Endometriosis and Tubal Infertility Factor
}

\author{
Teja Fabjan, ${ }^{1,3}$ Eda Vrtačnik-Bokal, ${ }^{2}$ Irma Virant-Klun, ${ }^{2}$ Jure Bedenk, ${ }^{2}$ \\ Kristina Kumer ${ }^{1,3}$ and Joško Osredkar ${ }^{1,3, *}$ \\ ${ }^{1}$ University Medical Centre Ljubljana, Institute of Clinical Chemistry and Biochemistry, Njegoševa 4, \\ 1000 Ljubljana, Slovenia \\ ${ }^{2}$ University Medical Centre Ljubljana, Division of Gynaecology, Department of Human Reproduction, Šlajmerjeva 3, \\ 1000 Ljubljana, Slovenia \\ ${ }^{3}$ University of Ljubljana, Faculty of Pharmacy, Aškerčeva cesta 7, 1000 Ljubljana \\ ${ }^{*}$ Corresponding author: E-mail: josko.osredkar@kclj.si
}

Received: 01-29-2020

\begin{abstract}
Oxidative stress in the follicular fluid (FF) is thought to be responsible for the abnormal development of oocytes. In our study patients with polycystic ovarian syndrome (PCOS), endometriosis, and tubal infertility factor (TIF), and healthy women with a male factor of infertility, were prospectively enrolled. From each patient, a sample of individual FF was collected from a dominant follicle. Concentration levels of TAS, 8-IP, 8-OHdG, and AMH were determined.

In women with PCOS, we found significantly lower values of oxidative stress markers in the FF. 8-IP and TAS levels were lower in the FF of women with endometriosis. In women with TIF, we also found significantly lower values of all tested markers in the FF, except for 8-OHdG and AMH. We wanted to see whether the biomarker measured in the FF in an individual diagnosis could predict a successfully obtained embryo from this particular follicle. The FF 8-OHdG result in PCOS patients stood out and proved to be a good predictive marker of matured and fertilized oocytes in these patients. Further research is needed to be able to apply the acquired knowledge in improving the outcome of IVF procedures.
\end{abstract}

Keywords: Oxidative stress; Antimüllerian hormone; Polycystic ovary syndrome; Endometriosis; Tubal infertility factor; Infertility

\section{Introduction}

The overall prevalence of infertility is $12.5 \%$ among women and $10.1 \%$ among men, and this rate is rising. The causes vary; among female diagnoses the most common are ovulation disorders, including PCOS, as well as endometriosis and various fallopian tubes defects. The prevalence of those seeking help has been reported even above $50 \% .{ }^{1}$ Environmental and lifestyle factors affect the couple's fertility status through a series of known and unknown mechanisms.

The reproductive organs have the highest number of mitochondria in the human body. ${ }^{2}$ This is needed because of the high requirement of energy production via ATP. On the other hand, this makes these organs highly susceptible to elevated levels of reactive oxygen or nitrogen species (ROS/RNS). Oxidative stress (OS) has received extensive attention in the past two decades due to the discovery that abnormal oxidation status is related to patients with chronic diseases, such as diabetes, cardiovascular, polycystic ovary syndrome (PCOS), endometriosis, cancer, and neurological diseases. ${ }^{3-6}$ Oxidative stress occurs when oxidants outnumber antioxidants, then products of peroxidation develop, and then pathological effects are caused by these phenomena. ROS are produced mainly within the mitochondrial electron transport chain and must be constantly deactivated to avoid excess formation to maintain normal cell function. ${ }^{7}$ 
In vitro fertilization (IVF) is a widely accepted infertility treatment and is often the only option for infertile couples to have a baby. Unfortunately, the success of this technique, measured as an average pregnancy rate per cycle, is only $30-40 \%$ for women under age $40 .^{8-10}$ Several studies have reported signs of oxidative stress in the FF of infertile women. ${ }^{711-14}$ It has been suggested that OS is responsible for normal oocyte development, due to DNA and cell membrane damage, which would then result in reduced oocyte quality, altered fertilization, and different embryo quality, implantation, and embryonic development. Elevated OS is also associated with ovarian ageing. Low-quality oocytes contain increased amounts of damaged DNA and chromosomal aneuploidy, secondary to age-related dysfunctions. ${ }^{15}$

It has been predicted that the concentration of AMH influences the number of oocytes retrieved during the IVF process. However, to date, the relationship between FF $\mathrm{AMH}$ and oocyte quality is unclear. The AMH level in the individual follicle was found to inversely correlate with the oocyte's maturity and developmental potential. ${ }^{16}$ In contrast, it was observed that oocytes capable of producing high levels of $\mathrm{AMH}$ were much easier to fertilize in normo-ovulatory females. ${ }^{17}$ In PCOS patients, however, it has even been shown that the proportion of mature oocytes, as well as fertilization success, does not correlate with FF AMH. ${ }^{18}$ In their study, Fanchin et al. showed that FF $\mathrm{AMH}$ is a better predictor of fertilization and implantation of embryo than serum AMH in normo-ovulatory women. ${ }^{19}$ In Korea, these results have recently been confirmed on a smaller sample. ${ }^{20}$ However, there have been very few studies on the relationship between FF AMH levels and the quality of oocyte and embryo.

The tubal factor of infertility, PCOS, and endometriosis are the main indications in patients undergoing IVF procedures. PCOS is a disease with high heterogeneity, and its clinical features mainly include menstrual disorder, secondary amenorrhea, serum hormone abnormalities, hirsutism, acne, obesity, and infertility. ${ }^{22}$ It is estimated that it affects $3-15 \%$ of all women. ${ }^{23}$ The primary cause of the disorder is an abnormality in the ovaries, but additional agents, such as obesity and environmental factors, affect the development of individual symptoms. ${ }^{24}$

Endometriosis is also one of the most common gynecologic diseases in women of reproductive age. It is characterized by implantation and growth of endometrial tissue (glands and stroma) outside the uterine cavity. Endometriosis is an estrogen-dependent pelvic inflammatory disease. The prevalence in women with pelvic pain ranges from $30-40 \%$ of the infertile population. Endometriosis can be also asymptomatic or accompanied by symptoms such as dysmenorrhea and dyspareunia. ${ }^{25,26}$ Many studies widely accepted that oxidative stress might be implicated in the pathophysiology of endometriosis causing a general inflammatory response in the peritoneal cavity. ${ }^{27-31}$

It is not known exactly how endometriosis causes infertility, but it is probably related to the inflammatory response resulting from the overproduction of prostaglandins, cytokines and macrophages, and natural killer cells. The inflammatory process thus impairs the function of the ovaries, peritoneal system, fallopian tubes, and endometrium and leads to impaired folliculogenesis, fertilization, and other conditions. Tubal infertility factor (TIF) accounts for about $35 \%$ of all infertility cases. ${ }^{32}$ Pregnancy does not occur due to mechanical obstruction in the fallopian tube. There are several causes for tubal blockage: infection, inflammation, surgery due to ectopic pregnancy, adhesions due to abnormal immunochemical environment, or rarely a congenital anomaly. ${ }^{33}$ Many studies use TIF patients as a control group because the obstacle is considered purely mechanical. We decided to include it as a pathological group because the causes of tubal infertility may also be hormonal (e.g. endometriosis) and inflammatory and this could have a significant impact on oxidative stress measurements.

The aim of this study was to evaluate OS in patients undergoing IVF procedure according to various indications, capabilities of fertilization, and embryo quality. We determined three different OS biomarkers and AMH in the FF of the dominant follicle containing oocyte. We have examined how their combination affects success rates in obtaining mature and fertilized oocytes in patients with PCOS, endometriosis, and TIF during IVF procedure.

\section{Selected Biomarkers}

\section{Antimüllerian hormone (AMH)}

$\mathrm{AMH}$ is produced in the granulosa cells and is a member of the transforming growth factor $\beta$ family. AMH is an excellent marker of ovarian reserves. ${ }^{34}$ The hormone levels in both the peripheral blood and intrafollicular fluid correspond with the rate of follicular maturation. AMH affects oocyte development during folliculogenesis, and the levels of AMH in the follicular fluid may affect the oocyte and embryo quality. ${ }^{20,35-37}$

\section{8-Isoprostane (8-IP)}

Free radical attack induces lipid peroxidation. Lipid peroxidation is a self-propagating phenomenon terminated by antioxidants and the measurement of products of lipid peroxidation has commonly been used to assess OS. Isoprostanes are a series of prostaglandin F2-like compounds, in vitro and in vivo formed by free radical-catalyzed peroxidation of phospholipid-bound arachidonic acid, a pathway that is independent of the cyclooxygenase pathway. ${ }^{38-40}$ F2-Isoprostanes are considered the best available biomarkers of oxidative stress status and lipid peroxidation. Measurement of the level of lipid peroxidation as reflected by $\mathrm{F} 2$-isoprostane concentrations in biological fluids may help to identify those patients most likely to benefit from antioxidant treatment. ${ }^{41,42}$ 


\section{8-hydroxy-2'-deoxyguanosine (8-OHdG)}

An oxidized derivative of deoxyguanosine is one of the most common oxidative modification in mutagenic damage and is used as a biomarker of OS. Oxidation of DNA occurs normally in vivo but also increases with exposure to oxidizing agents. Guanosines are very susceptible to oxidation, and this reaction can lead to $\mathrm{G}: \mathrm{C} \rightarrow \mathrm{T}: \mathrm{A}$ mutations. These mutations could have serious consequences. Oxidized bases are usually recognized and excised by special DNA repair machinery. ${ }^{43,44}$

\section{Total antioxidant status (TAS)}

The antioxidant defense system has many components. The total antioxidant status (TAS) of follicular fluid samples was determined using a special metric. The Randox TAS kit measures the total antioxidant capacity of a sample, i.e. anything that has an antioxidant effect, including both enzymatic and non-enzymatic antioxidants. The reaction rate is calibrated with Trolox, which is widely used as a traditional standard for TAS measurement assays, and the assay results are expressed in mmol Trolox equivalent/L. ${ }^{45,46}$

\section{Materials and Methods}

\section{1. Participants}

A total of 197 women with an indication for IVF/ ICSI treatment were prospectively enrolled in this study from March 2013 to April 2014 at University Medical Centre Ljubljana, Reproductive Medicine Unit. The research was approved by the ethics committee from the Slovenian National committee on medical ethics. Written informed consent was obtained from all participants. The study included four different groups: 36 patients with polycystic ovarian syndrome (PCOS), 72 with endometriosis, 41 with TIF, and 48 healthy controls. Healthy women whose in- fertility issues were caused by male partners were enrolled as controls. The demographic characteristics of the patient groups and control group are presented in Table 1.

Figure 1 shows the number and share of all eggs collected and further the embryos during observation in this study. In our study, 197 dominant follicles were aspirated. Oocytes were obtained in $54 \%$ of these follicles. $81 \%$ of the oocytes were mature and $74 \%$ of these were fertilized. In this study group, 64 embryos were obtained and of these, 54 were successfully transferred at the end.

\section{2. Samples Collection}

All women underwent ovarian stimulation using a combination of GnRH analogues and gonadotrophins. On the day of oocyte retrieval, the FF from the dominant follicle was aspirated. FF aspiration was performed transvaginally using a transvaginal ultrasound probe as a guide, and a specific oocyte aspiration needle connected to a closed vacuum system. Only FF samples without blood clots were used for the measurements, so as to minimize any possible interference with the photometric assay. Blood contamination was evaluated by visual inspection, and samples that appeared cloudy or bloodstained were discarded. The FF samples collected were centrifuged at $3500 \mathrm{rpm}$ for $10 \mathrm{~min}$ (to precipitate blood cells and to remove cellular components). All samples were stored at $-80{ }^{\circ} \mathrm{C}$ until assayed.

\section{3. Sample Analysis}

The effect of oxidative stress was measured by 8 - isoprostane and 8-hydroxy-2'-deoxyguanosine and enzymatic antioxidant activity by TAS (the combined effect of all antioxidants). Expression levels of AMH, 8-IP, 8-OHdG and TAS levels were determined by using commercially available enzyme-linked immunosorbent assay (ELISA)

Table 1: Demographic characteristics of the participants (mean or median of individual biomarkers are statistically analyzed and the $p$ values indicating the significance of differences between different infertility groups individually with control group obtained by the t test or Mann-Whitney test as appropriate)

\begin{tabular}{|c|c|c|c|c|c|c|c|}
\hline & Endometriosis & & PCOS & & $\begin{array}{l}\text { Tubal factor } \\
\text { of infertility }\end{array}$ & & $\begin{array}{l}\text { Control } \\
\text { group }\end{array}$ \\
\hline $\mathbf{N}$ & 72 & & 36 & & 41 & & 48 \\
\hline $\begin{array}{l}\text { Age [years]; } \\
(95 \% \mathrm{CI} \\
\text { for the mean) }\end{array}$ & $\begin{array}{c}33.8 \\
(33.1-34.5)\end{array}$ & $P=0.0013$ & $\begin{array}{c}\mathbf{3 0 . 8} \\
(29.4-32.2)\end{array}$ & $\mathrm{P}=0.3621$ & $\begin{array}{c}32.3 \\
(31-33.5)\end{array}$ & $\mathrm{P}=0.1597$ & $\begin{array}{c}31.62 \\
(30.5-32.7)\end{array}$ \\
\hline $\begin{array}{l}\text { Height }[\mathrm{cm}] ; \\
(95 \% \mathrm{CI} \\
\text { for the mean) }\end{array}$ & $\begin{array}{c}165.9 \\
(164.3-167.5)\end{array}$ & $\mathrm{P}=0.1746$ & $\begin{array}{c}\mathbf{1 6 4 . 8} \\
(162.8-166.7)\end{array}$ & $P=0.0310$ & $\begin{array}{c}\mathbf{1 6 7 . 5} \\
(165.8-169.2)\end{array}$ & $\mathrm{P}=0.9985$ & $\begin{array}{c}\mathbf{1 6 7 . 4} \\
(165.9-169.1)\end{array}$ \\
\hline $\begin{array}{l}\text { Weight [kg] } \\
\text { ( } 95 \% \text { CI } \\
\text { for the mean) }\end{array}$ & $\begin{array}{c}\mathbf{6 0 . 3} \\
(58.5-62.0)\end{array}$ & $P=0.0292$ & $\begin{array}{c}\mathbf{7 0 . 7} \\
(65.1-76.3)\end{array}$ & $\mathrm{P}=0.0582$ & $\begin{array}{c}\mathbf{6 5 . 3} \\
(61.6-69)\end{array}$ & $\mathrm{P}=0.6207$ & $\begin{array}{c}\mathbf{6 3 . 4} \\
(61.1-65.8)\end{array}$ \\
\hline $\begin{array}{l}\text { BMI } \\
\text { ( } 95 \% \text { CI } \\
\text { for the median) }\end{array}$ & $\begin{array}{c}\mathbf{2 1 . 6 5} \\
(21.2-22.5)\end{array}$ & $\mathrm{P}=0.3831$ & $\begin{array}{c}24.5 \\
(23-27)\end{array}$ & $P=0.0111$ & $\begin{array}{c}\mathbf{2 2 . 4 5} \\
(21.2-24)\end{array}$ & $\mathrm{P}=0.7096$ & $\begin{array}{c}22.45 \\
(21.4-23.3)\end{array}$ \\
\hline
\end{tabular}




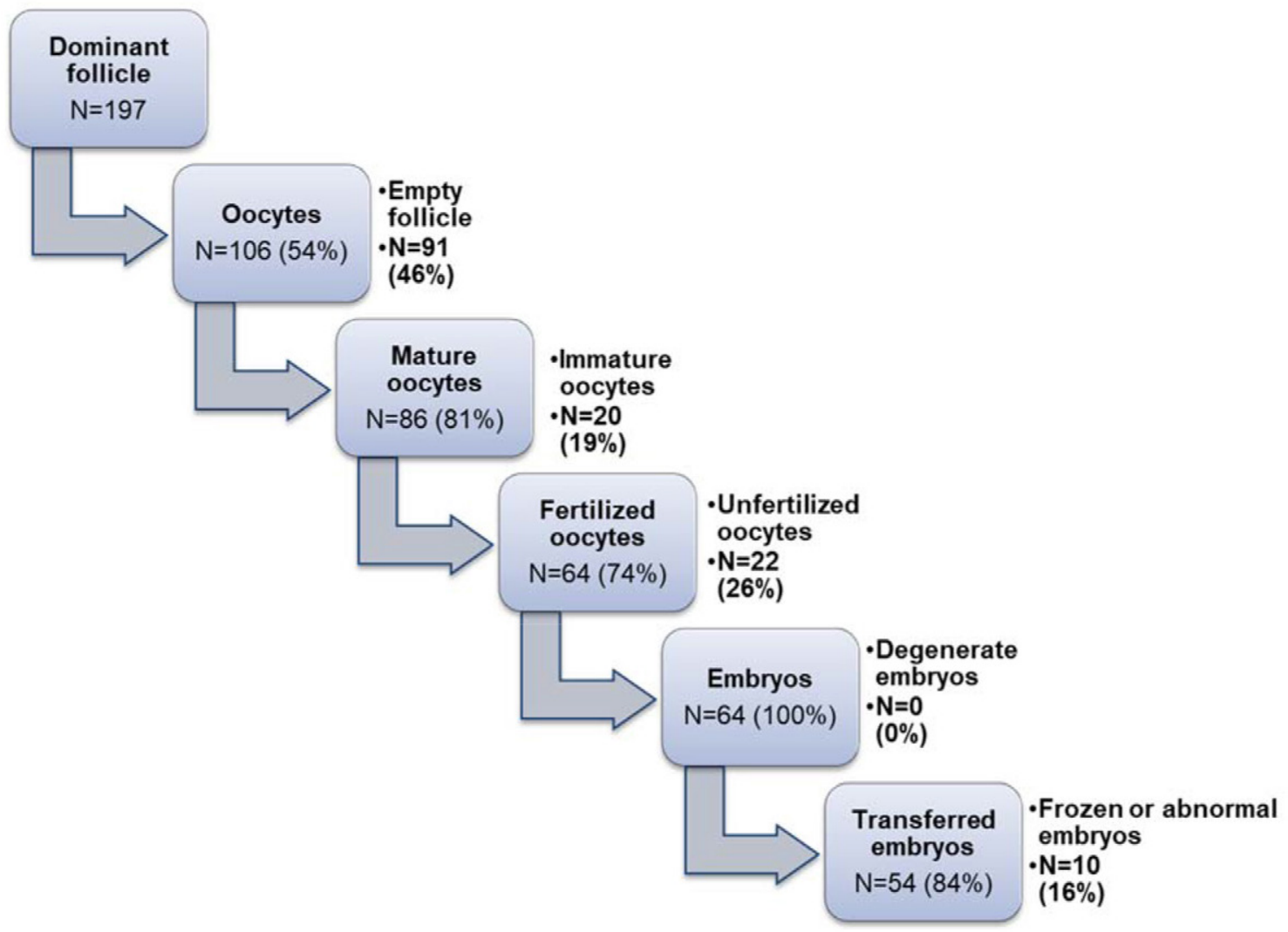

Figure 1: Outcome of IVF procedure in patients enrolled in the study by stages

kits according to the manufacturer's instructions. For 8-IP (Cayman Chemical Company, USA), ${ }^{47}$ 8-OHdG (JaICA - Japan Institute for the Control of Aging, Japan $)^{48}$ and AMH (Anshlab) ${ }^{49}$ the lower and upper detection limits were estimated as $0.8-500 \mathrm{ng} / \mathrm{L} ; 0.5-200 \mathrm{ng} / \mathrm{mL}$ and 3.8-1091 ng/L, respectively. Total antioxidant status (TAS) was evaluated by colourimetric method with Randox assay (Randox Laboratories Limited, UK). ${ }^{50}$

The results of the tests used are presented in Table 2.

\section{4. Statistical Analysis}

Statistical significance was calculated by two different tests: the Mann-Whitney U test. This test is non-parametric and does not require the groups to be normally distributed; it is more stable to outliers. The predictive value of biomarkers was determined using the "Receiver Operating Characteristic" analysis (ROC). P-values $<0.05$ were considered as significant. All analyses were made with statistical program Medcalc.

Table 2: Characteristic of the tests

\begin{tabular}{llccc}
\hline & Measuring & $\begin{array}{c}\text { Intra-assay } \\
\text { Range }\end{array}$ & $\begin{array}{c}\text { Inter-assay } \\
\text { variation (\%CV) }\end{array}$ & \begin{tabular}{c} 
variation (\%CV) \\
\hline AMH [pg/mL]
\end{tabular} \\
& Low & $14.2-15.5$ & 4.7 & 6.9 \\
& Medium & $80.0-80.8$ & 2.9 & 4.3 \\
& High & $609.6-942.8$ & 3.0 & 4.5 \\
\hline 8-IP [pg/mL] & Low & $0.80-5.10$ & 20.0 & 11.1 \\
& Medium & $12.80-32.00$ & 7.7 & 17.4 \\
& High & $80.00-500.00$ & 12.2 & 13.5 \\
\hline 8-OHdG [ng/mL] & Low & $8.6-10.2$ & 2.9 & 6.1 \\
& Medium & $28.5-32.2$ & 1.8 & 4.0 \\
& High & $107.3-129.7$ & 5.5 & 5.4 \\
\hline TAS & Low & $0.9-1.23$ & 5.1 & 4.1 \\
& Medium & $1.59-1.75$ & 1.8 & 3.0 \\
& High & $2.10-2.40$ & 1.3 & 3.9 \\
\hline
\end{tabular}




\section{Results}

Follicular fluid from the dominant follicle of 197 women undergoing IVF was analyzed in this study. The groups were generally comparable with each other; only patients with endometriosis were slightly older on average. The BMI index is higher in patients with PCOS as expected. The basal levels of serum hormones that affect the characteristics of infertility indications are presented in Table 3. The different diagnosis groups show variations in the levels of different hormones where it is typically expected, e.g. LH is elevated in the PCOS group.

The analyzed data are summarized in Table 4 and presented graphically in Figure 2.

Table 3: Hormonal status of the participants

\begin{tabular}{lrrrrrrr}
\hline \multicolumn{2}{c}{$\begin{array}{c}\text { Endometriosis } \\
\mathbf{N = 7 2}\end{array}$} & & $\begin{array}{c}\text { PCOS } \\
\mathbf{N}=\mathbf{3 6}\end{array}$ & & $\begin{array}{c}\text { TIF } \\
\mathbf{N}=\mathbf{4 1}\end{array}$ & $\begin{array}{c}\text { Control } \\
\text { group } \\
\mathbf{N}=\mathbf{4 8}\end{array}$ \\
\hline S-FSH & 7.4 & $\mathrm{P}=0.5454$ & 6.0 & $\mathbf{P}=\mathbf{0 . 0 0 8 5}$ & 6.6 & $\mathrm{P}=0.2103$ & 7.1 \\
S- $\mathbf{L H}$ & 4.1 & $\mathrm{P}=0.9681$ & 11.2 & $\mathbf{P}<\mathbf{0 . 0 0 0 1}$ & 3.8 & $\mathrm{P}=0.4426$ & 4.1 \\
S-PRL & 10.2 & $\mathrm{P}=0.7682$ & 10.5 & $\mathrm{P}=0.9602$ & 10.4 & $\mathrm{P}=0.9093$ & 10.6 \\
\hline
\end{tabular}

Table 4: Medians of individual biomarkers and interquartile ranges analyzed and the $\mathrm{p}$ values indicating the significance of differences between different groups of patients obtained by the Mann-Whitney U test

\begin{tabular}{|c|c|c|c|c|c|c|c|}
\hline & $\operatorname{PCOS}(\mathrm{N}=36)$ & & $\begin{array}{l}\text { Endometriosis } \\
\qquad(N=72)\end{array}$ & & $\begin{array}{l}\text { Endometriosis } \\
\qquad(\mathrm{N}=72)\end{array}$ & & $\begin{array}{c}\text { TIF } \\
(\mathrm{N}=41)\end{array}$ \\
\hline $\begin{array}{l}\text { 8-OHdG } \\
{[\mathrm{ng} / \mathrm{mL}]}\end{array}$ & $\begin{array}{c}6.82 \\
(4.66-11.45)\end{array}$ & $P=0.0001$ & $\begin{array}{c}15.11 \\
(8.76-23.45)\end{array}$ & $\begin{array}{l}\text { 8-OHdG } \\
{[\mathrm{ng} / \mathrm{mL}]}\end{array}$ & $\begin{array}{c}15.11 \\
(8.76-23.45)\end{array}$ & $\mathrm{P}=0.7539$ & $\begin{array}{c}16.32 \\
(9.77-22.41)\end{array}$ \\
\hline $\begin{array}{l}\text { 8-IP } \\
{[\mathrm{pg} / \mathrm{mL}]}\end{array}$ & $\begin{array}{c}85.97 \\
(58.81-313.12)\end{array}$ & $\mathrm{P}=0.9682$ & $\begin{array}{c}91.07 \\
(60.15-170.09)\end{array}$ & $\begin{array}{l}8-\mathrm{IP} \\
{[\mathrm{pg} / \mathrm{mL}]}\end{array}$ & $\begin{array}{c}91.07 \\
(60.15-170.09)\end{array}$ & $\mathrm{P}=0.5985$ & $\begin{array}{c}91.78 \\
(47.14-213.51)\end{array}$ \\
\hline $\begin{array}{l}\text { TAS } \\
{[\mathrm{mmol} / \mathrm{L}]}\end{array}$ & $\begin{array}{c}0.965 \\
(0.880-1.010)\end{array}$ & $P=0.0001$ & $\begin{array}{c}1.08 \\
(0.945-1.160)\end{array}$ & $\begin{array}{l}\text { TAS } \\
{[\mathrm{mmol} / \mathrm{L}]}\end{array}$ & $\begin{array}{c}1.08 \\
(0.945-1.160)\end{array}$ & $P=0.0002$ & $\begin{array}{c}0.92 \\
(0.858-1.008)\end{array}$ \\
\hline \multirow[t]{2}{*}{$\begin{array}{l}\mathrm{AMH} \\
{[\mathrm{U} / \mathrm{mL}]}\end{array}$} & $\begin{array}{c}6.85 \\
(3.49-11.26)\end{array}$ & $P=0.0093$ & $\begin{array}{c}3.52 \\
(2.06-6.56)\end{array}$ & $\begin{array}{l}\mathrm{AMH} \\
{[\mathrm{U} / \mathrm{mL}]}\end{array}$ & $\begin{array}{c}3.52 \\
(2.06-6.56)\end{array}$ & $P=0.0340$ & $\begin{array}{c}5.54 \\
(3.63-8.15)\end{array}$ \\
\hline & $\operatorname{PCOS}(\mathrm{N}=36)$ & & $\begin{array}{c}\text { TIF } \\
(\mathrm{N}=41)\end{array}$ & & $\begin{array}{l}\text { Endometriosis } \\
\qquad(\mathrm{N}=72)\end{array}$ & & $\begin{array}{l}\text { Healthy } \\
(\mathrm{N}=48)\end{array}$ \\
\hline $\begin{array}{l}\text { 8-OHdG } \\
{[\mathrm{ng} / \mathrm{mL}]}\end{array}$ & $\begin{array}{c}6.82 \\
(4.66-11.45)\end{array}$ & $P=0.0001$ & $\begin{array}{c}16.32 \\
(9.77-22.41)\end{array}$ & $\begin{array}{l}\text { 8-OHdG } \\
{[\mathrm{ng} / \mathrm{mL}]}\end{array}$ & $\begin{array}{c}15.11 \\
(8.76-23.45)\end{array}$ & $\mathrm{P}=0.8262$ & $\begin{array}{c}14.81 \\
(9.12-25.59)\end{array}$ \\
\hline $\begin{array}{l}8-\mathrm{IP} \\
{[\mathrm{pg} / \mathrm{mL}]}\end{array}$ & $\begin{array}{c}85.97 \\
(58.81-313.12)\end{array}$ & $\mathrm{P}=0.6357$ & $\begin{array}{c}91.78 \\
(47.14-213.51)\end{array}$ & $\begin{array}{l}\text { 8-IP } \\
{[\mathrm{pg} / \mathrm{mL}]}\end{array}$ & $\begin{array}{c}91.07 \\
(60.15-170.09)\end{array}$ & $P<0.0001$ & $\begin{array}{c}253.36 \\
(125.47-556.10)\end{array}$ \\
\hline $\begin{array}{l}\text { TAS } \\
{[\mathrm{mmol} / \mathrm{L}]}\end{array}$ & $\begin{array}{c}0.965 \\
(0.880-1.010)\end{array}$ & $\mathrm{P}=0.3712$ & $\begin{array}{c}0.92 \\
(0.858-1.008)\end{array}$ & $\begin{array}{l}\text { TAS } \\
{[\mathrm{mmol} / \mathrm{L}]}\end{array}$ & $\begin{array}{c}1.08 \\
(0.945-1.160)\end{array}$ & $\mathrm{P}<0.0001$ & $\begin{array}{c}1.275 \\
(1.150-1.355)\end{array}$ \\
\hline \multirow[t]{2}{*}{$\begin{array}{l}\mathrm{AMH} \\
{[\mathrm{U} / \mathrm{mL}]}\end{array}$} & $\begin{array}{c}6.85 \\
(3.49-11.26)\end{array}$ & $\mathrm{P}=0.3814$ & $\begin{array}{c}5.54 \\
(3.63-8.15)\end{array}$ & $\begin{array}{l}\text { AMH } \\
{[\mathrm{U} / \mathrm{mL}]}\end{array}$ & $\begin{array}{c}3.52 \\
(2.06-6.56)\end{array}$ & $\mathrm{P}=0.0895$ & $\begin{array}{c}4.64 \\
(2.69-8.18)\end{array}$ \\
\hline & $\operatorname{PCOS}(\mathrm{N}=36)$ & & $\begin{array}{l}\text { Healthy } \\
(\mathrm{N}=48)\end{array}$ & & $\begin{array}{c}\text { TIF } \\
(\mathrm{N}=41)\end{array}$ & & $\begin{array}{l}\text { Healthy } \\
(N=48)\end{array}$ \\
\hline $\begin{array}{l}\text { 8-OHdG } \\
{[\mathrm{ng} / \mathrm{mL}]}\end{array}$ & $\begin{array}{c}6.82 \\
(4.66-11.45)\end{array}$ & $P=0.0001$ & $\begin{array}{c}14.81) \\
(9.12-25.59\end{array}$ & $\begin{array}{l}\text { 8-OHdG } \\
{[\mathrm{ng} / \mathrm{mL}]}\end{array}$ & $\begin{array}{c}16.32 \\
(9.77-22.41)\end{array}$ & $\mathrm{P}=0.9672$ & $\begin{array}{c}14.81 \\
(9.12-25.59)\end{array}$ \\
\hline $\begin{array}{l}8-\mathrm{IP} \\
{[\mathrm{pg} / \mathrm{mL}]}\end{array}$ & $\begin{array}{c}85.97 \\
(58.81-313.12)\end{array}$ & $P=0.0005$ & $\begin{array}{c}253.35 \\
(125.47-556.10)\end{array}$ & $\begin{array}{l}8-\mathrm{IP} \\
{[\mathrm{pg} / \mathrm{mL}]}\end{array}$ & $\begin{array}{c}91.78 \\
(47.14-213.51)\end{array}$ & $\mathrm{P}<0.0001$ & $\begin{array}{c}253.35 \\
(125.47-556.10)\end{array}$ \\
\hline $\begin{array}{l}\text { TAS } \\
{[\mathrm{mmol} / \mathrm{L}]}\end{array}$ & $\begin{array}{c}0.965 \\
(0.880-1.010)\end{array}$ & $\mathrm{P}<0.0001$ & $\begin{array}{c}1.275 \\
(1.150-1.355)\end{array}$ & $\begin{array}{l}\text { TAS } \\
{[\mathrm{mmol} / \mathrm{L}]}\end{array}$ & $\begin{array}{c}0.92 \\
(0.858-1.008)\end{array}$ & $\mathrm{P}<0.0001$ & $\begin{array}{c}1.275 \\
(1.150-1.355)\end{array}$ \\
\hline $\begin{array}{l}\mathrm{AMH} \\
{[\mathrm{U} / \mathrm{mL}]}\end{array}$ & $\begin{array}{c}6.85 \\
(3.49-11.26)\end{array}$ & $\mathrm{P}=0.2306$ & $\begin{array}{c}4.64 \\
(2.69-8.18)\end{array}$ & $\begin{array}{l}\mathrm{AMH} \\
{[\mathrm{U} / \mathrm{mL}]}\end{array}$ & $\begin{array}{c}5.54 \\
(3.63-8.15)\end{array}$ & $\mathrm{P}=0.6537$ & $\begin{array}{c}4.64 \\
(2.69-8.18)\end{array}$ \\
\hline
\end{tabular}


In women with PCOS, we found significantly lower values of oxidative stress markers in the FF (8-IP: 73.21 vs. $253.36 \mathrm{pg} / \mathrm{mL}, \mathrm{P}=0.0001$; 8-hydroxy-2-deoxyguanosine: 6.82 vs. $14.81 \mathrm{ng} / \mathrm{mL}, \mathrm{P}=0.0001$ and total antioxidant status: 0.97 vs. $1.28 \mathrm{mmol} / \mathrm{L}, \mathrm{P}<0.0001)$ and no difference in AMH concentration ( 6.9 vs. $4.6 \mathrm{U} / \mathrm{mL}, \mathrm{P}=0.2306)$ compared with the control group.

8-IP levels were also significantly lower in the FF of women with endometriosis (90.11 vs. $253.36 \mathrm{pg} / \mathrm{mL}$, $\mathrm{P}<0.0001)$ compared to control group. TAS levels were also lower in $\mathrm{FF}$ of endometriosis patients (1.08 vs. 1.28 $\mathrm{mmol} / \mathrm{L}, \mathrm{P}<0.0001)$. No significant differences were found in FF-8-OHdG (15.11 vs. $14.81 \mathrm{ng} / \mathrm{mL}, \mathrm{P}=0.8262)$ and in FF-AMH (3.5 vs. $4.6 \mathrm{U} / \mathrm{mL}, \mathrm{P}=0.0895)$ between endometriosis and control group. In women with TIF, we also found significantly lower values of oxidative stress markers in the FF (8-IP: 57.18 vs. $253.36 \mathrm{pg} / \mathrm{mL}, \mathrm{P}=0.0001$; and TAS: 0.97 vs. $1.28 \mathrm{mmol} / \mathrm{L}, \mathrm{P}<0.0001)$ and no difference in $8-O H d G$ concentration: 16.32 vs. $14.81 \mathrm{ng} / \mathrm{mL}, \mathrm{P}$ $=0.0001$ and $\mathrm{AMH}$ concentration $(5.5$ vs. $4.6 \mathrm{U} / \mathrm{mL}, \mathrm{P}=$ $0.6537)$ compared with the control group.

In the second part, we aimed to relate our results to the outcome of the IVF procedure and determine whether a single biomarker measured in the follicular fluid in an individual diagnosis could predict a successfully obtained matured and fertilized cell from that particular follicle.

Figure 2 shows the accuracy measured by the area under the ROC curve (AUC). The area measures discrimination, i.e. the test's ability to correctly classify those with and without high-quality embryos ready for transfer. An area of 1 represents a perfect test; an area of 0.5 represents a worthless test. Of all the analyses shown, the FF 8-OHdG result in PCOS patients stood out and proved to be a very good predictive marker of obtaining a mature oocyte and of successful fertilization in these patients. At the limit of
$6.18 \mathrm{ng} / \mathrm{mL}$, with a sensitivity of $85.7 \%$ and a specificity of $86.4 \%, 8$-OHdG separated those with a mature and those with immature oocyte ( $\mathrm{p}<0.0001)$. 8-OHdG also separated those PCOS patients with a fertilized and those with unfertilized oocyte ( $\mathrm{p}<0.0001)$, also at the limit $6.18 \mathrm{ng} /$ $\mathrm{mL}$, with sensitivity of $84.62 \%$ and specificity of $82.61 \%$. Figure 2 graphically shows both ROC curves for this biomarker. All other markers of OS and also AMH showed poor predictive value both in predicting obtaining a mature cell from a particular follicle and in obtaining fertilization.

\section{Discussion}

In this study we confirmed for the first time that FF 8-OHdG is a good predictive biomarker for oocyte maturity and fertilization in PCOS patients.

The evaluation of the pathophysiology of a couple's infertility has shown that oxidative stress (OS) may be one of the causative factors of female infertility, as recent studies shown. ${ }^{11,28,51-53}$ But so far there is still a big gap in our knowledge and understanding of individual mechanisms, and further research is needed to be able to use the acquired knowledge to improve the outcome of IVF procedures. Many degenerative changes to the oocytes during ageing are due to oxidative stress. We evaluate OS in patients attended to IVF procedure according to different indicators and we have come up with some very interesting results.

We therefore decided in the present study also to include AMH as one of the investigated markers in the FF. AMH levels did not differ significantly between subjects with PCOS, endometriosis, TIF, and the control. However, an interesting trend suggesting lower concentrations
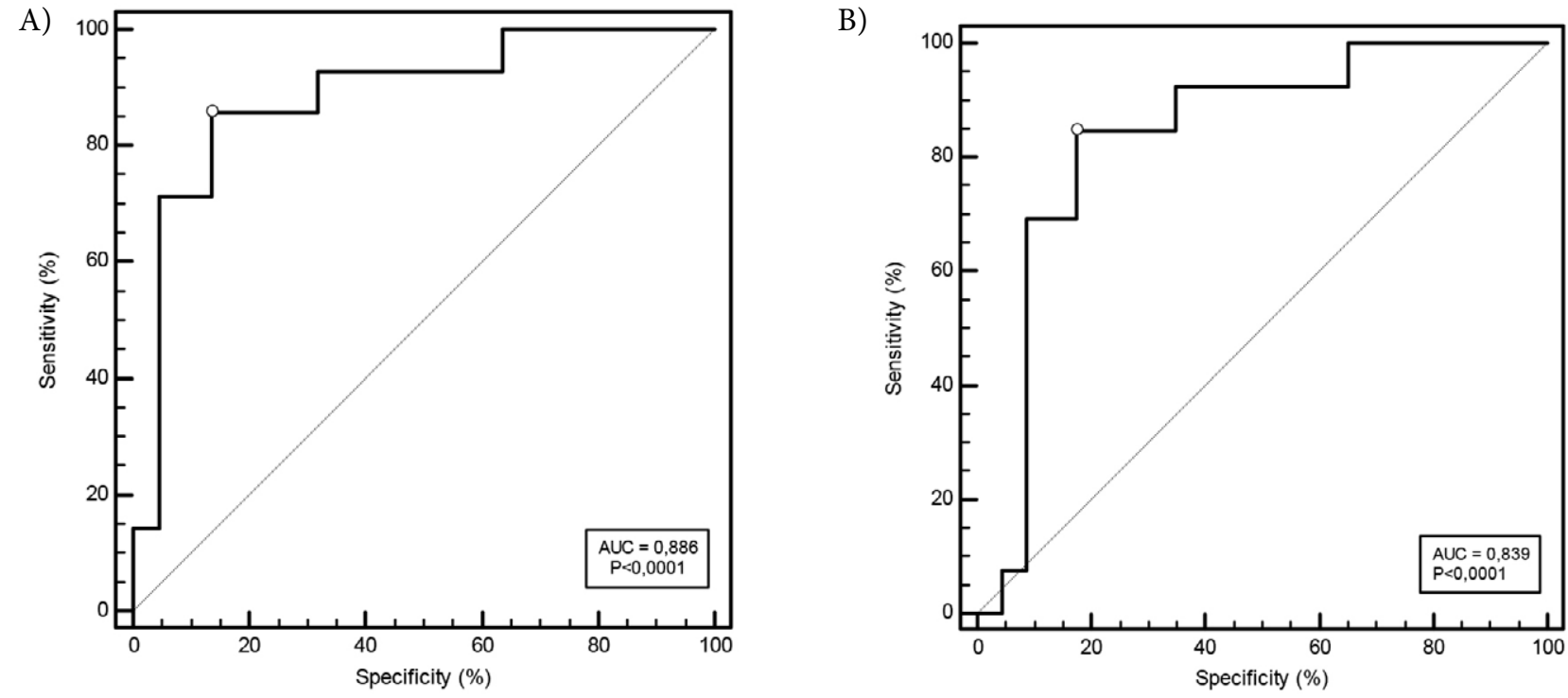

Figure 2: ROC curve for 8-OHdG in PCOS patient group classify on two different outcomes (A-mature oocytes; B-fertilized oocytes) 
of $\mathrm{AMH}$ is in the group of patients with endometriosis. Lower concentrations of AMH in FF of the leading follicle in patients with endometriosis were also detected in the Spanish research group. ${ }^{54}$ They also observed that the presence of the endometrioma itself reduce even further $\mathrm{AMH}$ concentration in the surrounding follicles and suggest that these results could be useful when counselling patients regarding their reproductive outcome. In the PCOS group, we detected slightly higher concentrations of AMH in FF, which is comparable to the study conducted by Liu et al. ${ }^{55} \mathrm{AMH}$ production starts in the very small follicles. The peak of production is reached and then the production rapidly declines. AMH production within the follicles is the part of the mechanism responsible for selection of the pre-ovulatory follicle. ${ }^{56}$ All follicles in our study were leading follicles of similar size, so a similar concentration of AMH is expected. In the TIF group, we did not detect a significant difference in the concentration of AMH in the follicular fluid as expected. Similarly, others have noted this, although they regarded this group as a control group. ${ }^{57,58}$

Another objective of our study was to determine the degree of oxidative stress in vivo in follicular fluid. Our results show some interesting differences between patients with PCOS, endometriosis, and TIF compared with healthy controls. The measured 8-IP concentration was found to be significantly higher in the control group than in all three patient groups. It is unclear why we obtained such results. One would expect to see less harmful OS products in healthy patients. A possible reason would be that patients are more concerned about the process and are taking more antioxidant supplements. There are known examples in the literature where vitamin supplements affect the concentration of lipid peroxidation products. Obesity and smoking can also affect the concentration of 8-IP. ${ }^{59}$ A recent meta-analysis showed that the intake of various antioxidant supplements can alter plasma F2-isoprostane concentrations. ${ }^{60}$ However, we do not know what this means for concentrations in follicular fluid. There are only a few studies in which the concentration of FF 8-IP is measured. Malhotra et al. found that the 8-IP concentration is associated with abortion rates and is higher in patients with PCOS. But, unlike us, they took the whole pool of follicle fluid and not just the leading follicle. However, TIF patients were taken as the control group. In these patients, we also have a slightly lower 8-IP concentration, but the difference is not significant. ${ }^{61}$ In their pilot study, Lin and colleagues found a lack of correlation between 8-IP levels and age, and further found that similar 8-IP levels between the right and left follicles suggests that oxidative stress affects both ovaries equally. ${ }^{62}$ Pier analyzed the concentration of 8-IP in the follicular fluid using mass spectrometry and reached a similar conclusion, namely, the 8-IP concentration did not significantly increase with the age of the patients. Additionally, he also did not detect an increase in 8-IP concentration associated with PCOS or endometriosis. They concluded that these findings are at odds with the conventional assumption that 8 -IP is a marker for oxidative stress. Instead, they suggested that F2-isoprostanes in FF may have functions unrelated to stress or inflammation. ${ }^{63}$ To date, we have not found any other researches that would measure 8-IP in follicular fluid. Some studies measured peritoneal fluid and plasma levels of 8-IP in vivo in patients with endometriosis. They found that concentrations in both the urine and peritoneal fluid of patients with endometriosis were significantly elevated compared to those of controls. ${ }^{64,65}$ Calzada et al. measured plasma 8-IP concentrations in patients with PCOS. They found that the level of 8-IP in patients was significantly increased. Our results in follicular fluid did not confirm this, as in our case the concentration of 8-IP was significantly increased in the control group. Based on all this information, it is difficult to conclude exactly what our results mean. Perhaps the 8-IP concentration in the follicular fluid from the leading follicle is not similar to that in other body fluids. Our study also shows that the concentration of 8-IP in the leading follicle has a weak effect on the effectiveness of the IVF procedure. It should be emphasized that our results of 8-IP measurements were very scattered in all groups, and some cross-reactivity might have occurred. According to the manufacturer's instructions, some types of sample may contain contaminants that interfere with the analysis. It is also known that several different prostaglandin derivatives are present in the follicular fluid. ${ }^{47,66}$ We estimate that this assay is not good for testing in follicle fluid and therefore no significant conclusions can be drawn from concentrations in this analyze. Due to the lack of clarity and poor research, further studies are needed.

Our measurements of 8-OHdG in the leading follicle show similar concentration in controls and patients with endometriosis. This runs contrary to a study done in Bra$\mathrm{zil}^{6}{ }^{67}$ where higher follicular concentrations of 8 -OHdG were found in the endometriosis group compared to controls. A more recent study of OS in endometriosis patients led to results similar to ours. ${ }^{68}$ The concentration of 8-OHdG was similar in the control group to that of patients with endometriosis. But in both studies, all of the follicular fluid was used, not only from the leading follicle. In discussing the reasons for such a result it is worth mentioning the very interesting information that $8-\mathrm{OHdG}$ also exhibited ROS-suppressing properties in several in vitro models, suggesting its possible involvement in the fine tuning of the response to OS. ${ }^{69} \mathrm{In}$ fact, there are already several studies that investigate the mechanism where 8-OHdG sometimes show antioxidant or anti-inflammatory-like activity that can be attributed to the Rac1-GTP pathway. ${ }^{70-72}$ We further failed to find a difference in the concentration of 8-OHdG between the TIF and control groups, which is consistent with extant findings. ${ }^{57}$ In patients with PCOS, the concentration of 8-OHdG in leading follicular fluid is significantly lower. Our result is consistent with other 
studies, where authors have claimed that decreased serum levels of 8-OHdG can reflect an enfeebled repair of oxidative DNA damage or enhanced antioxidant defense rather than low ROS production in PCOS tissue. High ROS levels are well known to promote the expression of antioxidant enzymes. ${ }^{73}$ Therefore, overexpression of these antioxidants may lead to suppression of the extent of oxidative stress and consequently to the prevention of ROS interactions with DNA, thereby diminishing 8-OHdG formation. Several studies have reported that major antioxidant enzymes are significantly induced in subjects with PCOS compared to healthy subjects. ${ }^{74,75}$ Metformin therapies have also been shown to have the effect of lowering 8-OHdG levels in the serum of patients with PCOS, which also might be a reason for our results in follicular fluid. Metformin is a drug commonly used in the treatment of insulin resistance, which is very common in obese patients with PCOS, so a correlation is possible but as yet unverified. ${ }^{76}$ It would certainly be necessary to investigate further and determine in more detail the causes of such results. To begin with, the activity of the DNA glycosylase-repairing enzymes in FF should be checked.

The results of our antioxidant status measurements show statistically significant higher TAS concentrations in the FF of healthy women compared to individual patients group (PCOS, endometriosis and also TIF). Our results are in perfect agreement with the rest of the literature. Some also found a positive association between FF TAS and clinical pregnancy rates. ${ }^{77,78}$

A very interesting and maybe most important finding that our research showed was that the concentration of 8-OHdG in PCOS group in the particular follicle showed a strong association with a mature and with a fertilized oocyte. As far as we know, to date, no one has tried to relate the concentration of 8 -OHdG to the outcome of the IVF procedure in patients with PCOS. We have found that 8-OHdG, measured in a particular follicular fluid, can very well predict the acquisition of a mature egg and the successful fertilization of that egg. Anyway, our study alone is not enough and this link must be checked further on a larger sample. But if these results hold, the FF 8-OHdG could be a useful predictive marker for the individual oocyte in the artificial insemination procedure in PCOS patients.

\section{Conclusion}

OS plays a role in several physiological processes, from oocyte maturation to fertilization and embryo development. There is burgeoning literature on the involvement of OS in the pathophysiology of infertility, assisted fertility, and female reproduction. What we do know is that the role of OS in female reproduction cannot be underestimated. Our study revealed a few significant differences in the concentrations of individual markers of oxidative stress and AMH between groups with different diagnoses. But the most interesting finding, one that is definitely worth exploring further, is the strong relationship between the concentration of 8-OHdG in follicular fluid and the obtaining of a useful mature cell from this follicle in PCOS patients, as well as the successful fertilization in the end of IVF procedure.

\section{Acknowledgments}

The authors would like to thank all the women in IVF programs who agreed to participate in the study, and to Vera Troha who processed samples in lab.

Research funding: This study was financed by the Ministry of Science and Education through the Young Researchers program. The funding organizations played no role in the study design, in the collection, analysis, and interpretation of data, in the writing of the report, or in the decision to submit the report for publication. Ethical approval for this study was obtained from the Republic of Slovenia’s National Medical Ethics Committee (108/02/13).

\section{References}

1. J. Datta, M. J. Palmer, C. Tanton, L. J. Gibson, K. G. Jones, W. Macdowall, A. Glasier, P. Sonnenberg, N. Field, C. H. Mercer, et al., Hum. Reprod. 2016, 31, 2108-18.

DOI:10.1093/humrep/dew123

2. S. Gupta, G. Ahmad, M. Tran, G. Al Hayaza, Z. Kayali, in: A. Agarwal (Ed.), R. Sharma, S. Gupta, A. Harlev, G. Ahmad, S. S. du Plessis, S. C. Esteves, S. M. Wang: Oxidative stress in Human Reproduction, Springer Nature, Cham, Switzerland, 2017, pp. 107-128

3. S. Reuter, S. C. Gupta, M. M. Chaturvedi, B. B. Aggarwal, Free Radic. Biol. Med. 2010, 49, 1603-16.

DOI:10.1016/j.freeradbiomed.2010.09.006

4. R. De Bont, N. van Larebeke, Mutagenesis 2004, 19, 169-85. DOI:10.1093/mutage/geh025

5. G. Scutiero, P. Iannone, G. Bernardi, G. Bonaccorsi, S. Spadaro, C. A. Volta, P. Greco, L. Nappi, Oxid. Med. Cell. Longev. 2017, 2017, 1-7. DOI:10.1155/2017/7265238

6. I. Dalle-Donne, R. Rossi, R. Colombo, D. Giustarini, A. Milzani, Clin. Chem. 2006, 52, 601-23.

DOI:10.1373/clinchem.2005.061408

7. A. Agarwal, A. Aponte-Mellado, B. J. Premkumar, A. Shaman, S. Gupta, Reprod. Biol. Endocrinol. 2012, 10, 49. DOI:10.1186/1477-7827-10-49

8. D. R. Meldrum, K. M. Silverberg, M. Bustillo, L. Stokes, Fertil. Steril. 1998, 69, 1005-1009.

DOI:10.1016/S0015-0282(98)00083-1

9. J. J. Wade, V. MacLachlan, G. Kovacs, Aust. New Zeal. J. Obstet. Gynaecol. 2015, 55, 473-476. DOI:10.1111/ajo.12356

10. R. Nuñez-Calonge, S. Cortés, L. M. Gutierrez Gonzalez, R. Kireev, E. Vara, L. Ortega, P. Caballero, L. Rancan, J. Tres- 
guerres, Reprod. Biomed. Online 2016, 32, 446-456. DOI:10.1016/j.rbmo.2015.12.010

11. P. J. Devine, S. D. Perreault, U. Luderer, Biol. Reprod. 2012, 86, 27. DOI:10.1095/biolreprod.111.095224

12. A. Agarwal, S. Gupta, R. Sharma, Reprod. Biomed. Online 2005, 11, 641-50. DOI:10.1016/S1472-6483(10)61174-1

13. O. Oyawoye, A. Abdel Gadir, A. Garner, N. Constantinovici, C. Perrett, P. Hardiman, Hum. Reprod. 2003, 18, 2270-4.

14. M. Becatti, R. Fucci, A. Mannucci, V. Barygina, M. Mugnaini, L. Criscuoli, C. Giachini, F. Bertocci, R. Picone, G. Emmi, et al., Int. J. Mol. Sci. 2018, 19. DOI:10.3390/ijms19020592

15. A. Agarwal, A. Aponte-Mellado, B. J. Premkumar, A. Shaman, S. Gupta, Reprod. Biol. Endocrinol. 2012, 10, 49. DOI:10.1186/1477-7827-10-49

16. S. Cupisti, R. Dittrich, A. Mueller, R. Strick, E. Stiegler, H. Binder, M. W. Beckmann, P. Strissel, Eur. J. Med. Res. 2007, 12, 604-8.

17. C. Takahashi, A. Fujito, M. Kazuka, R. Sugiyama, H. Ito, K. Isaka, Fertil. Steril. 2008, 89, 586-591.

DOI:10.1016/j.fertnstert.2007.03.080

18. R. Mashiach, A. Amit, J. Hasson, S. Amzalzg, B. Almog, D. Ben-Yosef, J. B. Lessing, R. Limor, F. Azem, Fertil. Steril. 2010, 93, 2299-2302. DOI:10.1016/j.fertnstert.2009.01.125

19. R. Fanchin, D. H. Mendez Lozano, N. Frydman, A. Gougeon, N. di Clemente, R. Frydman, J. Taieb, J. Clin. Endocrinol. Metab. 2007, 92, 1796-1802.

DOI:10.1210/jc.2006-1053

20. J. H. Kim, J. R. Lee, H. J. Chang, B. C. Jee, C. S. Suh, S. H. Kim, J. Korean Med. Sci. 2014, 29, 1266.

DOI:10.3346/jkms.2014.29.9.1266

21. S. Arabzadeh, G. Hossein, B. H. Rashidi, M. A. Hosseini, H. Zeraati, Ann. Saudi Med. 2010, 30, 442-447.

DOI:10.4103/0256-4947.71063

22. Rotterdam ESHRE/ASRM-Sponsored PCOS Consensus Workshop Group, Fertil. Steril. 2004, 81, 19-25.

23. S. Wołczyński, W. Zgliczyński, in: Large Interna - Endocrinology, Medical Tribune Poland, Warsaw, 2012, pp. 561-567. DOI: $10.17219 /$ acem $/ 59380$

24. S. Bednarska, A. Siejka, Adv. Clin. Exp. Med. 2017, 26, 359367.

25. A. Augoulea, A. Alexandrou, M. Creatsa, N. Vrachnis, I. Lambrinoudaki, Arch. Gynecol. Obstet. 2012, 286, 99-103. DOI:10.1007/s00404-012-2357-8

26. N. Singh, K. Lata, M. Naha, N. Malhotra, A. Tiwari, P. Vanamail, J. Hum. Reprod. Sci. 2014, 7, 143-7. DOI:10.4103/0974-1208.138874

27. G. Christodoulakos, A. Augoulea, I. Lambrinoudaki, V. Sioulas, G. Creatsas, Eur. J. Contracept. Reprod. Heal. Care 2007, 12, 194-202. DOI:10.1080/13625180701387266

28. A. Augoulea, G. Mastorakos, I. Lambrinoudaki, G. Christodoulakos, G. Creatsas, Gynecol. Endocrinol. 2009, 25, 7581. DOI: $10.1080 / 09513590802485012$

29. G. Scutiero, P. Iannone, G. Bernardi, G. Bonaccorsi, S. Spadaro, C. A. Volta, P. Greco, L. Nappi, Oxid. Med. Cell. Longev. 2017, 2017, 1-7. DOI:10.1155/2017/7265238

30. A. Mulgund, S. Doshi, A. Agarwal, in: Handbook of Fertility,
Elsevier, Amsterdam, 2015, pp. 273-281.

DOI:10.1016/B978-0-12-800872-0.00025-1

31. Yavuz, N. E. Aydin, O. Celik, E. Yilmaz, E. Ozerol, K. Tanbek, J. Cancer Res. Ther. 2014, 10, 324.

DOI:10.4103/0973-1482.136619

32. M. G. Hull, C. M. Glazener, N. J. Kelly, D. I. Conway, P. A. Foster, R. A. Hinton, C. Coulson, P. A. Lambert, E. M. Watt, K. M. Desai, Br. Med. J. (Clin. Res. Ed). 1985, 291, 1693-7. DOI:10.1136/bmj.291.6510.1693

33. G. D. Adamson, V. L. Baker, Best Pract. Res. Clin. Obstet. Gynaecol. 2003, 17, 169-185.

DOI:10.1016/S1521-6934(02)00146-3

34. E. W. Freeman, M. D. Sammel, H. Lin, C. R. Gracia, J. Clin. Endocrinol. Metab. 2012, 97, 1673-1680.

DOI:10.1210/jc.2011-3032

35. B. Abu-Fakher, F. Al-Quobaili, M. Alhalabi, Middle East Fertil. Soc. J. 2013, 18, 110-114.

DOI:10.1016/j.mefs.2012.12.005

36. B. Wiweko, U. Anggraheni, E. Mansyur, T. Yuningsih, A. K. Harzief, G. Pratama, K. Sumapraja, M. Natadisastra, A. Hestiantoro, Asian Pacific J. Reprod. 2016, 5, 361-364.

DOI:10.1016/j.apjr.2016.07.011

37. R. Fanchin, J. Taieb, D. H. M. Lozano, B. Ducot, R. Frydman, J. Bouyer, Hum. Reprod. Oxford Engl. 2005, 20, 923-927. DOI:10.1093/humrep/deh688

38. B. Piłacik, T. W. Nofer, W. Wąsowicz, Int. J. Occup. Med. Environ. Health 2002, 15, 19-27.

39. M. Janicka, A. Kot-Wasik, J. Kot, J. Namieśnik, Int. J. Mol. Sci. 2010, 11, 4631-59. DOI:10.3390/ijms11114631

40. M. Comporti, C. Signorini, B. Arezzini, D. Vecchio, B. Monaco, C. Gardi, Mol. Aspects Med. 2008, 29, 43-49.

DOI:10.1016/j.mam.2007.09.011

41. M. Comporti, C. Signorini, B. Arezzini, D. Vecchio, B. Monaco, C. Gardi, Free Radic. Biol. Med. 2008, 44, 247-56.

DOI:10.1016/j.freeradbiomed.2007.10.004

42. P. Montuschi, P. J. Barnes, L. J. Roberts, FASEB J. 2004, 18, 1791-800. DOI:10.1096/fj.04-2330rev

43. Y. Guo, J. Weck, R. Sundaram, A. E. Goldstone, G. Buck Louis, K. Kannan, Environ. Sci. Technol. 2014, 48, 9804-9811. DOI:10.1021/es5024898

44. A. C. Pereira, F. Martel, Cell Biol. Toxicol. 2014, 30, 301-312. DOI:10.1007/s10565-014-9285-2

45. O. Erel, Clin. Biochem. 2005, 38, 1103-1111. DOI:10.1016/j.clinbiochem.2005.08.008

46. I. Marrocco, F. Altieri, I. Peluso, Oxid. Med. Cell. Longev. 2017, 2017, 6501046. DOI:10.1155/2017/6501046

47. Cayman Chemical, 8-Isoprostane ELISA Kit, https://www. caymanchem.com/product/516351, (assessed: March 20, 2019).

48. Japan Institute for the Control of Aging (JaICA), Highly Sensitive 8-OHdG Check ELISA kit, http://www.jaica.com/e/ products_dna_8ohdg_kit_hs.html, (assessed: March 20, 2019).

49. Ansh Labs, AMH(pico) ELISA kit, https://www.anshlabs. com/product/picoamh-elisa/, (assessed: March 21, 2019)

50. Randox Laboratories, Total Antioxidant Status reagent, 
https://www.randox.com/total-antioxidant-status/, (assessed: March 20, 2019)

51. E. Ozturk, T. Oge, Y. Aydin, O. Isiklar, H. Hassa, 2018, 49, 136-139.

52. Á. Várnagy, T. Kőszegi, E. Györgyi, S. Szegedi, E. Sulyok, V. Prémusz, J. Bódis, Hum. Fertil. 2018, 1-9.

DOI:10.1080/14647273.2018.1535719

53. M. Becatti, R. Fucci, A. Mannucci, V. Barygina, M. Mugnaini, L. Criscuoli, C. Giachini, F. Bertocci, R. Picone, G. Emmi, et al., Int. J. Mol. Sci. 2018, 19, 592. DOI:10.3390/ijms19020592

54. J. A. Garcia-Velasco, L. Motta, S. Rodriguez, M. Toribio, J. Martinez-Salazar, A. Pacheco, J. Endometr. 2009, 1, 52-56. DOI:10.1177/228402650900100108

55. X. Y. Liu, Y. J. Yang, C. L. Tang, K. Wang, J. J. Chen, X. M. Teng, Y. C. Ruan, J. Z. Yang, Fertil. Steril. 2019, 111, 157-167. DOI:10.1016/j.fertnstert.2018.09.022

56. J. V. Jeppesen, R. A. Anderson, T. W. Kelsey, S. L. Christiansen, S. G. Kristensen, K. Jayaprakasan, N. Raine-Fenning, B. K. Campbell, C. Yding Andersen, Mol. Hum. Reprod. 2013, 19,519-527. DOI:10.1093/molehr/gat024

57. C. S. Campos, D. Vaamonde, C. Andreoli, A. C. Martins, V. K. Genro, C. A. Souza, R. Chapon, J. S. L. Cunha-Filho, Reprod. Biomed. Online 2010, 21, 470-473.

DOI:10.1016/j.rbmo.2010.05.007

58. R. Kucera, V. Babuska, Z. Ulcova-Gallova, V. Kulda, O. Topolcan, Syst. Biol. Reprod. Med. 2018, 64, 220-223.

DOI:10.1080/19396368.2018.1450906

59. G. Block, C. D. Jensen, J. D. Morrow, N. Holland, E. P. Norkus, G. L. Milne, M. Hudes, T. B. Dalvi, P. B. Crawford, E. B. Fung, et al., Free Radic. Biol. Med. 2008, 45, 377-84. DOI:10.1016/j.freeradbiomed.2008.04.005

60. T. J. van 't Erve, Redox Biol. 2018, 17, 284-296. DOI:10.1016/j.redox.2018.05.003

61. N. Malhotra, K. Gongadashetti, R. Dada, N. Singh, Fertil. Steril. 2014, 102, 86. DOI:10.1016/j.fertnstert.2014.07.291

62. K. Lin, K. Barnhart, A. Shaunik, S. Butts, G. A. Fitzgerald, C. Coutifaris, Fertil. Steril. 2005, 84, 47.

DOI:10.1016/j.fertnstert.2005.07.112

63. B. Pier, J. W. Edmonds, L. Wilson, A. Arabshahi, R. Moore, G. W. Bates, J. K. Prasain, M. A. Miller, Prostaglandins Other Lipid Mediat. 2018, 134, 7-15.

DOI:10.1016/j.prostaglandins.2017.11.001

64. I. Sharma, L. K. Dhaliwal, S. C. Saha, S. Sangwan, V. Dhawan, Fertil. Steril. 2010, 94, 63-70.

DOI:10.1016/j.fertnstert.2009.01.141
65. G. Polak, I. Wertel, B. Barczyński, W. Kwaśniewski, W. Bednarek, J. Kotarski, Eur. J. Obstet. Gynecol. Reprod. Biol. 2013, 168, 187-190. DOI:10.1016/j.ejogrb.2012.12.043

66. B. Pier, J. W. Edmonds, L. Wilson, A. Arabshahi, R. Moore, G. W. Bates, J. K. Prasain, M. A. Miller, Prostaglandins Other Lipid Mediat. 2018, 134, 7-15

DOI:10.1016/j.prostaglandins.2017.11.001

67. M. G. Da Broi, F. O. de Albuquerque, A. Z. de Andrade, R. L. Cardoso, A. A. Jordão Junior, P. A. Navarro, Cell Tissue Res. 2016, 366, 231-242. DOI:10.1007/s00441-016-2428-4

68. Á. Várnagy, T. Köszegi, E. Györgyi, S. Szegedi, E. Sulyok, V. Prémusz, J. Bódis, Hum. Fertil. 2018, 1-9.

DOI:10.1080/14647273.2018.1535719

69. C. Y. Ock, K. S. Hong, K.-S. Choi, M.-H. Chung, Y. Kim, J. H. Kim, K.-B. Hahm, Biochem. Pharmacol. 2011, 81, 111-122. DOI:10.1016/j.bcp.2010.08.023

70. J. Y. Huh, D. J. Son, Y. Lee, J. Lee, B. Kim, H. M. Lee, H. Jo, S. Choi, H. Ha, M. H. Chung, Free Radic. Biol. Med. 2012, 53, 109-121. DOI:10.1016/j.freeradbiomed.2012.03.023

71. D. H. Kim, I. H. Cho, H. S. Kim, J. E. Jung, J. E. Kim, K. H. Lee, T. Park, Y. M. Yang, S. Y. Seong, S. K. Ye, M. H. Chung, J. Chinese Med. Assoc. 2006, 38, 417. DOI:10.1038/emm.2006.49

72. H. S. Kim, S. K. Ye, I. H. Cho, J. E. Jung, D. H. Kim, S. Choi, Y. S. Kim, C. G. Park, T. Y. Kim, J. W. Lee, M. H. Chung, Free Radic. Biol. Med. 2006, 41, 1392.

DOI:10.1016/j.freeradbiomed.2006.07.018

73. H. Sova, L. Morin-Papunen, U. Puistola, P. Karihtala, Fertil. Steril. 2010, 94, 2670-3.

DOI:10.1016/j.fertnstert.2010.03.049

74. W. Atiomo, S. Khalid, S. Parameshweran, M. Houda, R. Layfield, BJOG An Int. J. Obstet. Gynaecol. 2009, 116, 137-143. DOI:10.1111/j.1471-0528.2008.02041.x

75. N. K. Kuşçu, A. Var, Acta Obstet. Gynecol. Scand. 2009, 88, 612-617. DOI:10.1080/00016340902859315

76. H. Sova, U. Puistola, L. Morin-Papunen, P. Karihtala, Fertil. Steril. 2013, 99, 593-598.

DOI:10.1016/j.fertnstert.2012.10.013

77. A. K. Singh, R. Chattopadhyay, B. Chakravarty, K. Chaudhury, Reprod. Toxicol. 2013, 42, 116-124.

DOI:10.1016/j.reprotox.2013.08.005

78. N. Yilmaz, H. A. Inal, U. Gorkem, A. Sargin Oruc, S. Yilmaz, A. Turkkani, J. Obstet. Gynaecol. (Lahore). 2016, 36, 654-657. DOI:10.3109/01443615.2016.1148683 


\section{Povzetek}

Oksidativni stres v folikularni tekočini (FF) naj bi bil odgovoren za nenormalen razvoj oocitov. V našo raziskavo so bile prospektivno vključene pacientke s sindromom policističnih jajčnikov (PCOS), endometriozo in tubarnim dejavnikom neplodnosti (TIF) ter zdrave ženske $\mathrm{z}$ dejavnikom moške neplodnosti. Od vsake bolnice je bil odvzet vzorec FF iz dominantnega folikla. Določene so bile koncentracije TAS, 8-IP, 8-OHdG in AMH.

Pri ženskah s PCOS smo ugotovili bistveno nižje vrednosti označevalcev oksidativnega stresa v FF. Stopnje 8-IP in TAS so bile v FF žensk z endometriozo nižje. Pri ženskah s TIF smo ugotovili tudi bistveno nižje vrednosti vseh testiranih označevalcev v FF, razen za 8-OHdG in AMH. Želeli smo videti, ali lahko označevalec, izmerjen v FF pri posamezni diagnozi, napoveduje uspešnost pridobitve zarodka iz tega folikla. Rezultat 8-OHdG v FF pri pacientkah s PCOS je izstopal in se je izkazal za dober napovedni označevalec dozorelih in oplojenih oocitov pri teh pacientkah. Potrebne so nadaljnje raziskave, da bi lahko pridobljeno znanje uporabili za izboljšanje rezultatov postopkov IVF. 